\title{
MAGNUS ERLENDSSON AND RULER MARTYRDOM ON THE SCANDINAVIAN AND SLAVIC PERIPHERY OF MEDIEVAL EUROPE'
}

\author{
Simon Malmenvall
}

DOI: 10.17846/CL.2021.14.1.23-38

\begin{abstract}
MALMENVALL, Simon. Magnus Erlendsson and Ruler Martyrdom on the Scandinavian and Slavic Periphery of Medieval Europe. From the early tenth to early twelfth centuries the eastern and northern periphery of Europe was composed of polities which had recently adopted Christianity. Here, a special common type of veneration of the saints emerged - ruler martyrs, such as Wenceslaus of Bohemia (died in 935), Boris and Gleb of Kievan Rus' (died in 1015), Magnus Erlendsson of Orkney (died between 1115 and 1117), etc. This type of sainthood refers to saints characterized by a martyr's death caused out of political self-interest by Christians themselves. One of the most representative saints pertaining to the phenomenon of ruler martyrs is jarl (earl) Magnus Erlendsson of the Orkney Isles, then part of the Norwegian kingdom. The internal political plot led by a close relative, the jarl's nonresistance on principle, and the slaughter of the innocent victim resembling Christ all this recalls the manner of the deaths of some Slavic princes of the time, for example, Boris and Gleb of Kievan Rus'. Magnus and other ruler martyrs from that period together formed a new tradition of sainthood, previously unknown both in the Byzantine Empire and Southern (Latin) Europe, where the murdered ruler eventually became a saint who could legitimize the self-esteem of newly Christianized peoples and position them in the symbolic center of the Christian world.
\end{abstract}

Keywords: Magnus Erlendsson, Orkney Isles, medieval Scandinavia, Boris and Gleb, Kievan Rus', hagiographies, ruler martyrs, medieval literature

\section{Introduction}

From the early tenth to early twelfth centuries the eastern and northern periphery of Europe, from Scandinavia and Rus' to the Slavic territories in the Balkans, was composed of polities which had recently adopted Christianity. Here, regardless of the rising cultural and doctrinal differences between the Western (Catholic) and Eastern (Orthodox) Christianity, a special common type of veneration of the saints emerged - ruler martyrs, such as Wenceslaus of Bohemia (died in 935), Boris and Gleb of Kievan Rus' (died in 1015), Jovan Vladimir of Dioclea (present-day Montenegro) (died in 1016), Canute IV Svensson of Denmark (died in 1086), and Magnus Erlendsson of Orkney (died between 1115 and 1117). This type of sainthood refers to saints characterized by a martyr's death caused out of political self-interest by Christians themselves, not by members of other religions or ideologies as a result of opposition against the Christian faith as such. One of the most representative saints pertaining to the phenomenon of ruler martyrs is jarl (earl) Magnus

This article is part of the postdoctoral basic research project in the field of theology "Z6-1883 Ruler Saints (Martyrs) on the Periphery of Medieval Europe: Kievan Rus', Norway, Dioclea" carried out at the Faculty of Law and Business Studies (Ljubljana) and financed by the Slovenian Research Agency (ARRS) from the state budget. 
Erlendsson of the Orkney Isles, then part of the Norwegian kingdom, which makes the central historical personality of this study. Together with the Scandinavian jarl, some similar representative cases, typologically comparable to Magnus Erlendsson, are taken into consideration, particularly those two from the East Slavic world, Boris and Gleb of Kievan Rus. This phenomenon served to build the self-esteem of the ecclesiastical and secular elites of the newly Christianized polities: through the emergence of the local saints, they regarded their homelands as equally included in the world of Christian culture and being part of the biblically inspired vision of history as "salvation history." 2 These saints became not only models showing the ideal ethical conduct of genuine Christian rulers, but also, at least by the mid-twelfth century, the patron saints of their respective peoples and lands (Antonín 2017, 110-111).

To better understand the historical, theological, and literary background of Magnus's martyrdom, a semiotic culturological method is applied. It is based on a deep analysis of the narratives of the original sources and their spiritual and sociocultural implications, enabling to grasp the self-understanding of the ecclesiastical and secular elites behind them. The same methodology, including the concept of "salvation history," was applied by the author of this study in several of his previous works ${ }^{3}$ dealing with the development of historical consciousness among the medieval Slavs belonging to the Eastern Orthodox ecclesiastical sphere after their official adoption of Christianity. On the one hand, all the studied saints are perceived as unique historical individuals who consciously decided to imitate Christ; on the other hand, however, they were part of particular sociocultural structures, fostering particular political needs in their homelands.

\section{Narrative sources and historiography}

Written testimonies on Magnus Erlendsson are provided by three main narrative sources belonging to the corpus of Old Norse sagas: Orkneyinga Saga (The Saga of the Earls of Orkney), Magnús Saga Lengri (Longer Magnus Saga), and Magnús Saga Skemmri (Shorter Magnus Saga). ${ }^{4}$ The Old Norse texts on Magnus, written between the mid-twelfth and the late thirteenth century, are interrelated and presumably had among their sources a lost Latin Vita sancti Magni. The account integrated into the predominantly secular Orkneyinga Saga - a collection of warrior and adventure tales about the deeds of the earls of Orkney - from the early thirteenth century ${ }^{5}$ can be supplemented, therefore, by the two separate Magnus sagas finalized in the second half of the thirteenth century: one of greater length (Magnus Saga Lengri) based on previous hagiographical material from the mid-twelfth century and the Orkneyinga Saga, and the other of lesser length (Magnus Saga

2 The concept of salvation history traces its origins back to the biblical exegesis in the late antiquity patristic period. The theological writers of that time interpreted the local and global historical processes in terms of the care of a loving God for mankind (Malmenvall 2017b, 68-69). Thus, they recognized God as someone "entering" into history in order to save mankind from the captivity of sin and provide it with the "fullness of life." Within relations ("encounters") between God and man, historically specific elements are placed in the context of repeatable, almost perpetual similarities (Malmenvall 2018, 89-90).

3 Such as: Malmenvall 2019a; 2019b; 2019c.

4 For the critical edition of the saga and hagiographical material on Magnus from which passages and information are used in this article, see: Guðmundsson 1965. The English translation with commentary of the same texts is available in: Vigfusson 1893. The English text of these sources follows the translation made by the author of this study consulting the mentioned English edition by Vigfusson.

5 In its near entirety Orkneyinga Saga is only preserved in the fourteenth-century codex Flateyjarbók (literally: "book from the flat island"), where it is interpolated into accounts on the two missionary kings of Norway, Olaf Tryggvason (995 - 1000) and Olaf Haraldsson or Saint Olaf (1015 - 1028, died in 1030). For the critical edition of Flateyjarbók, see: Vigfússon and Unger 1860 - 1868. 
Skemmri). The shorter Magnus saga is very similar to the content found in the Orkneyinga Saga. The description of the twelfth-century events constitutes the major part, from chapter 44 to 112 , of this saga and deals mainly with the rivalry between the two lines of the Orkney jarl dynasty stemming from the two sons of Porfinnr, Pall and Erlendr (both died 1098), in the course of which the Orkney Isles got their first saint, Magnus Erlendsson (Beuermann 2011, 136-137). On the other hand, the longer saga abounds with theological commentary and expressly draws on a Latin eulogy from the lost life of the saint composed by a certain "magister Robert," probably of AngloSaxon origin. Hence, among the mentioned three works, this text has the greatest hagiographical character (Antonsson 2007, 5-17; Jesch and Molleson 2006, 129-130, 132; Ingham 1973, 7, 15; Tomany 2008, 131-132).

The phenomenon of ruler martyrs on the eastern and northern periphery of medieval Europe has thus far never been presented in a unified historical-theological comparative study forming a coherent synthesis. This phenomenon has been only partly and fragmentarily addressed within various monographs and articles, mostly in the field of cultural history. Nevertheless, the subject of the ruler martyrs on the periphery of medieval Europe has thus far been concisely explored by Norman W. Ingham (1934 - 2015) (1984; 1990), an American cultural and literary historian, and Simon Malmenvall (2017a; 2019a; 2019b; 2019c), a Slovene historian and theologian. It was also addressed, as a comparative sketch on the medieval Slavic ruler martyrs, by Konstantin Aleksandrovich Kostromin (2016), a Russian ecclesiastical historian. In relation to previous research, the originality of these relatively new studies lies in their transnational and transconfessional approach.

A wider northern European political and cultural context of Magnus's life and death has been addressed by Haki Antonsson (2007), a contemporary Icelandic-British historian. His works, drawing from the tradition of Erich Hoffmann (1926 - 2005) (1975), a German historian, can be regarded as a breakthrough in studying both Magnus Erlendsson and saintly cults of the Scandinavian rulers in general. Among other authors from the twentieth century, at least two prominent researchers are worth mentioning: Finnbogi Guðmundsson, an Icelandic historian, as the editor of the most elaborate (Old Norse-Icelandic) critical edition (1965) of the textual corpus on Magnus Erlendsson, and John Mooney (1862 - 1950), a Scottish historian, as the author of a comprehensive study (1935) on the sources and events concerning Saint Magnus.

\section{Factual background of Magnus's martyrdom and veneration}

Jarl Magnus Erlendsson (1106 - 1115/1117) was a ruler of the semi-independent polity of the Orkney Archipelago, north of present-day Scotland, within the Norwegian kingdom. Sources on Magnus from the saga and hagiographic material agree that he was assassinated at Easter resembling the sacrifice of the "innocent Easter lamb," Jesus Christ - between 1115 and 1117 at the behest of his cousin, Haakon Palsson, who had rival claims to rule the Orkney Isles and for a time contrived to coexist by dividing the realm with Magnus. Consequently, he lured Magnus to a peace-meeting on the island of Egilsay, where his men lay in ambush. When the conspiracy had been revealed, the earl decided against violent resistance to spare the lives of his men. He went to the church and, after the mass, voluntarily surrendered to the murderers. The cousin then ordered Magnus's cook to behead his master. Soon after Magnus's death, miracles supposedly began occurring. In 1135, the local residents demanded the disinterment of his relics, but were opposed by both jarl Paul, Haakon's son, and bishop Vilhjalmr (William). Because of his disbelief, the bishop temporarily lost his sight and, under the strong impression of such a "divine sign," he finally ordered Magnus's tomb to be opened. Magnus was canonized the same year and his 
relics were translated to the church in Birsay, the political center of the Orkneys of the time. ${ }^{6}$ Two years later (1137) jarl Rognvald Kali Kolsson, later called Rognvald the Crusader (1136 - 1158), Magnus's nephew known as Saint Rognvald after his canonization in the late twelfth century, laid the foundations for the cathedral dedicated to Saint Magnus in Kirkwall, the new political and ecclesiastical center of the Orkney Isles (Guðmundsson 1965, 122-125; Antonsson 2006, 145; 2007, 69; Ingham 1973, 7-9).

Church dedications can reveal a certain dynamic of the popularity of his cult; it is remarkable that only one church dedication to Saint Magnus in Norway is known, whereas there were at least ten in Iceland. Since Magnus was only an earl, not a king, and since Saint Olaf was the spiritually "eternal" ruler of Norway, for centuries the hegemonic power of the Atlantic regions, the cult of Magnus might have assumed symbolic power for those smaller dominions. It is noticeable that the cathedral on the Streymoy Island in the Faroe Archipelago that was built at the beginning of the fourteenth century was dedicated to Magnus and received a relic of the saint from Orkney (Tomany 2008, 139; Antonsson 2006, 149; Blindheim 1988). Thus, Magnus can be symbolically regarded as a "periphery saint" in a twofold sense: the wider northern periphery of medieval Europe and the periphery concerning two minor semi-independent polies (Iceland and the Orkneys) within the medieval Scandinavian socio-cultural world.

The cult of Saint Magnus achieved official recognition with episcopal support. It is not clear what precisely motivated Vilhjalmr to act as he did. It can be presumed that the impending takeover of the earldom by Rognvald Kali Kolsson, Magnus's nephew, may have prompted Vilhjalmr to demonstrate his support for the cult of a close kinsman of the earldom's next ruler, who came to power in 1136/1137. Conversely, it would have been tempting for Rognvald to align his political ambitions with the memory of his martyred uncle; as his intention to keep power was to a considerable extent a competition for support among the local chieftains and clergy, he needed to identify himself with the (spiritual) history of the people over whom he aspired to rule (Antonsson 2006, 145; Thomson 1987, 61). The episcopal promotion of Magnus's cult can also be placed in a wider context: there was a tendency at that time among bishops in the Scandinavian lands to adopt native saints as patrons of their dioceses. For instance, from the beginning of the twelfth century onwards, the cult of Saint Olaf appears to have been closely associated with the bishops and later archbishops of Nidaros/Trondheim (Antonsson 2006, 147; Mortensen and Mundal 2003, 353-359). There were similar developments in Sweden, where the archdiocese of Uppsala upheld the sanctity of king Erik Jedvardsson (1156 - 1160). When Uppsala became the new see of the archbishop of Sweden in 1164, it had only been a regular episcopal see for about three decades. The archbishop and his clergy were therefore motivated to enhance Uppsala's prestige as a religious center; a royal cult, similar to Saint Olaf in Nidaros/Trondheim, provided an ideal opportunity (Antonsson 2006, 147; Lundegårdh 1997, 116-117; Bagge 2011, 177-178). Consequently, the cults of native saints played an important role in enhancing the identity of bishoprics during a formative period in the history of the Scandinavian Church. Bishops associated their own authority with the memory and miraculous powers of local saints. It is not a coincidence that the transference of the seat of the bishop of Orkney from Birsay to Kirkwall was accompanied by the translation of Saint Magnus's relics (Antonsson 2006, 147; 2007, 80-81).

6 There is no significant difference between the Magnus Saga Lengri, Magnus Saga Skemmri, and Orkneyinga Saga concerning the immediate events after Magnus's death resulting in the emergence of his cult. This includes also the particular reports on the alleged miracles in the form of healings occurring at his grave, which, on the other hand, make part of a hagiographical convention of the Christian medieval literature, Eastern and Western alike (Antonsson 2007, 69-70; Heinzelmann 1979, 52-66). 


\section{Magnus as the sign of the new Christian era}

According to the narrative in the Magnus Saga Lengri (Guðmundsson 1965, 335-383; Beuermann 2011, 140-141), Magnus, after a morally ideal childhood, becomes a Viking through the bad company of his fellow young warriors. The Norwegian king, Magnus Olafsson (1093 - 1103), takes his cousins, jarl Haakon and jarl Magnus, with him on his campaign to Wales. First, the king takes control of Orkney and the Hebrides with Magnus's and his cousin's collaboration. However, when the king attacks Wales, Magnus shows that he has abandoned his previous interests in war and riches and thus "converted" to the only true Lord, to whom he owes undivided loyalty. In fact, Magnus refuses to fight - he does not regard this land hostile and refuses to wage an "unjust" war. What Magnus does next is an act both of bravery in a religious sense and of revolt according to political circumstances. Magnus chooses to sit right in the middle of the fighters on the war ship, without cover, singing holy texts from the Book of Psalms by king David, the shining example of the righteous ruler. The battle concludes with a victory for the Norwegians, but one bought with severe losses. In this battle, the unprotected Magnus is miraculously saved by God and preserved "for a greater crown" in the future. Magnus's readiness to imitate Christ in any circumstances reach its climax and fulfillment in his readiness to die for the benefit of others. When he sees Haakon and his men approach, he knows that he has been betrayed but he does not run. He participates in the holy mass, takes his last Communion before Haakon's men come to capture him, and he forbids his men to defend him. Through these changes to the narrative, Magnus becomes like Christ, and like the son of God, who gave his own life for the peace and redemption of the world, Magnus gives his life for the peace and redemption of the people of Orkney. In this manner, the saintly jarl acts in full accordance with the general (western) medieval notion of a just government, based on the pre-Christian tradition of stoicism and Augustine's (354 - 430) referential work De Civitate Dei, which ought to be characterized by the ruler's love towards his lieges. Namely, at the center of the considerations on secular polities and the ethical role of rulers is the interpretation of Jesus Christ as a King-Priest who through his sacrifice on the cross and resurrection connected men with God. According to this notion, after Christ's ministry on earth, God entered the heart of every ruler, and every prince, king, or emperor became called to be his image (imago Dei) (Antonín 2017, 3-4).

Extensive comments of the longer saga give a coherent structure and meaning to Magnus's life and death. Without these theological explanations, the life and death of a ruler becomes ambiguous. When the "divine logic" of Magnus's reasoning is confronted with the "profane pragmatism" of his worldly counterparts, when his acts are presented without the explanation of their sacred meaning, his story at times verges on the ridiculous: a man sitting in the middle of battle but not taking up his arms, wedding but never consummating the marriage, fighting for his earldom for years in order to suddenly commit a suicidal act. Because of these clashes between the Old Norse warrior ethos and Christian conduct, the Magnus Saga Lengri must have relied on commentary to convey its message (Tomany 2008, 136).

Following the interpretation expressed in Magnus Saga Lengri, the Orkneys seem to be Christian in name, but pagan in reality. For instance, this source tells how Haakon Palsson visited a pagan soothsayer during a stay in Sweden in order to gauge his future (Guðmundsson 1965, 341343 ). It is a sentiment of this sort that the saga's writer or compiler, describing the events in a land "on the uttermost edge of the world," additionally explains in his prologue.

Praise glory and splendor and honor be to Almighty God, our redeemer and maker, for his manifold mercy and grace, which he bestows on us who dwell on the uttermost edge of the 
world; so that after the saying of the masters who so set it in their books, it seems to them as though we were come out of this world (Guðmundsson 1965, 335). ${ }^{7}$

Apparently, this "remote land" has been blessed by "God's grace," as he has granted it a saint. The notion of the "remoteness" and "semi-barbaric" character of the lands in Europe's north is expressed in many contemporary (Latin) sources outside Scandinavia. One such example can be found in the letter of Pope Gregory VII $(1073$ - 1085) from 1079 which is addressed to the Norwegian king Olaf III Haraldsson (1067 - 1093). In this letter, the pope asks Olaf not to interfere in the rivalry over the succession of the Danish throne between the sons of the late king Sven II Estridsson (1047 - 1076) and to send young Norwegian noblemen to the Roman curia for education, so that they could return to their own country to teach Christian doctrine or engage in royal administration. In this context, the pope addresses the king and his land as being "on the farthest edge of the circle of the globe" (Bagge 2011, 171-172; Vandvik 1959, 30).

In one sense the writer or compiler of the saga can be seen as a pioneer in writing the Christian history of a relatively newly converted land in the north of Europe. The hagiographers of the Scandinavian princely saints needed framework within which they could present the violent death of the rulers in terms of martyrdom (Antonsson 2007, 31-36). ${ }^{8}$ In this case, a part of the spiritual background of the relation between Haakon and Magnus is the Old Testament story about the Hebrew kings Saul and David (1 Sam 28): thus, Haakon's envy of Magnus echoes Saul's attitude towards the much more popular David; moreover, Haakon's meeting with a Swedish soothsayer has a certain correspondence in Saul's visit to the witch of Endor; obviously, Saul and Haakon seek help from a demonic medium in order to have their political future foretold and, in doing so, both break even their nominal faith in one God (Antonsson 2004, 58-59). Furthermore, the motif of the biblical tabernacle, or altar in a Christian sense, from the longer saga denotes Christianity, which Magnus, with his conduct during his life and the manner in which he dies, both completes and protects.

Each one bringeth such things as he hath means to bring into the tabernacle of God, as a help to mercy for himself. One gold, others silver, some gem-stones, some goat's hair and red buckskin; and such offerings are not to be contemptuously esteemed, for of such is made the covering over the tabernacle of God, to shield it and keep it from wet and sun-heat. [...] Gold denotes wit and wisdom; silver chastity; gem-stones the miracles of holy men; goatshair the repentance of sins; red buckskin martyrdom (Guðmundsson 1965, 336). ${ }^{9}$

The tabernacle signifies the final victory of Christianity in the region. In a re-enactment of Christ's crucifixion and his triumph over the Devil, Magnus's willingness to suffer martyrdom heralds the completion of one step in God's plan: the spread of the religion even to a remote land like

7 "Lof, dÿrä ok heiär ok æra sé almáttigum guäi, lausnara várum ok skapara, fyrir sína margföldu mildi ok miskunnsemi, er hann veitir oss, er byggjum á utanveräum jaäri heimsins, ok eptir meistaranna orätæki, er svá setja í sínar bækr, at beim sÿnist sem vér sém komnir út ór heiminum.”

8 On the earliest narrative literature dealing with the saints which created Christian historical myths for the relatively newly converted lands of Europe, see: Mortensen 2006.

9 "Пvílíkt færir hverr sem hann hefir föng á í landtjald guäs sér til hjálpar ok miskunnar: einn gull, aärir silfr, sumir gimsteina, sumir hafrahár ok rauäbukkaskinn; ok er slík fórn eigi svíviräiliga viräandi, bví at af slíku er gör yfirhöfn yfir landtjald guäs, at hlífa bví ok verja bat fyrir vætu ok sólarhita. [...] Gull merkir speki ok vizku, silfr hreinlífi, gimsteinar kraptaverk heilagra manna, hafrahár iäran synda, rauä bukkaskinn píslarvætti." 
the Orkneys. Magnus, however, does not convert his people to Christianity, for they are already Christians in name, but still his martyrdom represents a symbolic inclusion of the earldom into the family of Christian people. Magnus's innocent blood has washed away the violent pagan past, heralding a new era of the Orkney Isles. In this sense, the martyrdom of Magnus Erlendsson is interpreted as a battle between God and the Devil.

Now, for that no man can be Abel, save he who tolerates and proves the spite and envy of Cain (Gen 4: 1-6); and as the holy Ezekiel (Ezek 3-33) dwelt with the venomous men, and the righteous Lot (Gen 11-14; Gen 19) was hard pressed of wrongful men; so the foe of the whole human race waked up temptation, and the heat of persecution on all sides against this knight of God, sowing discord and hatred between brothers and kinsfolk and dear friends, all that he might hinder him, and make those wonders of none effect, which then began to grow with him (Guðmundsson 1965, 354)..$^{10}$

According to the passage above, the battle between God and his adversary within a specific local re-realization of salvation history is fought in the form of two historical figures, Haakon and Magnus, in an obscure location near the edge of the known world. With Magnus's death the Devil is defeated, and the people of the Orkney Isles are "baptized" with Magnus's innocent blood. On this basis, the spiritual reasoning behind comparing Magnus to innocent Abel and Haakon to murderous Cain is almost identical with the already explained Abel and Cain motif concerning other ruler martyr cults of the time - for example, the case of Boris and Gleb (Antonsson 2007, 38-40; Kantor 1983, 146-147).

The fact that the saints of this type were also political leaders and warriors in recently and only nominally Christianized territories had similar consequences for the literature and social consciousness both on the eastern and northern periphery of Europe. Worldly and religious images of the man may conflict, especially in those works where a continuing history is recounted, as in the Old Norse sagas on Magnus and the chronicle (Tale of Bygone Years) about Boris and Gleb. For example, Boris and Gleb were said to be motivated both by political morality in order to promote unity among the members of the ruling Rurik dynasty and the desire to "follow Christ." Thus, the very paradox of the strong yet meek saint, the warrior who chooses nonresistance, becomes attractive for the construction of a new image of saint, fostering patriotic self-affirmative notions among the ecclesiastical and secular elite of a particular polity (Waugh 2003, 9-10).

The martyrdom of Magnus Erlendsson and the phenomenon of medieval ruler martyrs in general can be additionally explained using the theory of "scapegoat mechanism" by René Girard (1923 - 2015) (1987, 235-245). According to him, archaic cultures encouraged the use of cyclical violence and the "scapegoat mechanism" was activated time and again in order to restore original peace - it pointed out a particular innocent victim, often perceived as a rival brother (Abel and Cain, Romulus and Remus, etc.), who was sacrificed for the renewal of a particular community. This pattern of cyclical violence was, argues Girard, defeated through the person of Jesus Christ who subverted this mechanism by voluntarily sacrificing his own life for the salvation of every person "once and for all." In this respect, an irreconcilable duality emerges between the archaic mythical world and the Gospel, violent sacrifice of someone's life for the alleged benefit of the

10 "Nú meä bví at engi má vera Abel nema sá, er bolir ok reynir nízku Kains ok öfund, ok inn helgi Ezechíel bjó meä eitrfullum mönnum ok inn réttláti Loth var bröngdr af ranglátum mönnum, bá vakti upp óvin alls mannkyns freistni ok bruna meingöräa alla vega í mót beim guäs. riddara, sándi sundrbykki ok hatri milli bræära ok frænda ok kærra vina, allt til fless at fyrirkoma honum ok ónÿta hans kraptaverk, er bá tóku at vaxa meä honum." 
community and voluntary sacrifice out of love for every irreplaceable human life (Petkovšek 2018, 37-40). The main difference between mimetic violence and the Christian worldview lies in their relation to the other: the Christian mindset presupposes love towards every person and without deception acknowledges the innocence of the victim. In this context, Magnus Erlendsson and other ruler martyrs of the northern and eastern periphery of medieval Europe, can be regarded as innocent victims following the example of Jesus Christ by voluntarily sacrificing themselves to save the lives of others. In this way, they succeeded in (symbolically) breaking the previous cycle of violence and, consequently, rejecting the recent pagan past.

\section{Typologically distinct sainthood on the European periphery}

Despite significant dissimilarities to the "classical" martyrs from the first centuries of Christianity, ruler martyrs were adapted and assimilated into a well-known phenomenon of martyrdom, the earliest widespread form of sainthood in the Mediterranean world (White 2010, 95-96, 101-102, 105; Hafner 1964, 15-17; Dubois 2008, 12-13). Although new lives of martyrs were no longer being produced in contemporary Byzantium or Latin (South) Europe, this type of sainthood proved to be a fruitful model on the recently Christianized eastern and northern periphery of Europe, from Scandinavia to Bohemia, from Rus' to the Slavic lands in the Balkans (White 2010, 105; Hafner 1964, 16-17). The phenomenon of ruler martyrs enabled the newly Christianized ruling dynasties and their homelands to position themselves in the symbolic center of the European culture of the time. This also explains why the first written records produced in the eastern and northern periphery of medieval Europe are all about local saints. From this perspective, not only did the earlier periphery become the center, but the division between the center and periphery lost its relevance. ${ }^{11}$ Wherever God's presence was manifested through a saintly ruler, his people were in the center of the Christian world (Trajković-Filipović 2012, 9-10; Klaniczay 2002, 327). Because those saints "followed Christ," their sacrifice is presented as a "new covenant" between God and their homeland. Here another level of meaning should be noted. Sacrifice is the key notion of martyrdom; in the Old Testament animal sacrifice was a way of making a covenant; through animal sacrifice God made a covenant with Abraham; in the later Christian tradition, Christ was compared to a lamb that was to be sacrificed by a divine plan for the sins of mankind. This level of meaning is important for the role of ruler martyrs of the tenth, eleventh, and twelfth centuries because their sacrifice was not only a manifestation of God's presence but also the making of a covenant and creation of a new Christian community (Trajković-Filipović 2012, 14-15; Sciacca 1990, 254-257).

King Canute IV Svensson of Denmark offers another Scandinavian case similar to those of jarl Magnus or the two Rus' princes, as he was assassinated by "jealous men" from within his own kingdom at Odense in present-day south-central Denmark in 1086. He was recognized as a martyr by the pope in 1100 (Ingham 1973, 6). The king was faced with a plot organized by his brothers and was forced to flee, taking refuge with a small band of men in the church of Saint Mary and Alban in Odense. There he prayed frequently and thought of the martyr Alban - an ancient saint from the British Isles who in the third century died for the Christian faith under Roman persecution wanting to follow in his footsteps and those of others crowned with "holy blood." Canute chose not to resist, took Holy Communion, and committed himself and his men to God. The mob outside

${ }_{11}$ Additionally, a fundamental (spiritual) equality among all Christians - despite their differences in gender, ethnicity, social status, etc. - elaborated already in the epistles of the apostle Paul should be emphasized. On the theological and culturological aspects of the (patristic) reception of the Pauline doctrine concerning equality, see: Lamprou and Zozul'aková 2019. 
threw stones and spears through the windows until a lance pierced the king through and, his arms spread in the form of a cross, he was pinned to the altar of Saint Alban by the spear in his side. His blood was thus spilled like a sacrifice on the altar of Christ. ${ }^{12}$ The interpretative key to his sainthood lies in his virtuous Christian life and most of all in the form of his death: his arms extended as in a crucifixion and the spear piercing his side as in the case of Christ's death, while the stones recalled Saint Stephen, the protomartyr from apostolic times, executed by stoning (Ingham 1973, 6-7; Acts 7).

It should be noted that the saga material on Magnus's martyrdom provides some obvious typological parallels particularly with the texts of the Boris and Gleb ${ }^{13}$ cycle written $^{14}$ at the turn of the eleventh and twelfth centuries. Magnus, like Boris and Gleb, decided against armed resistance to save the lives of his people; Magnus, like Gleb, was murdered by his own cook. The motif of the execution of a prince carried out by his servant probably had its origin in the shameful connotations associated with being killed by a social inferior, which additionally accentuated the image of Haakon as an evil murderer and Magnus as a victim (Price 1993, 108-109; Cubitt 2000, 79). In addition, bishop Vilhjalmr, like the Kiev metropolitan Georgi, initially questioned the sanctity of the murdered prince. The Boris and Gleb cycle could, in fact, have exerted at least some literary influence on the authors of the sagas and biographies about jarl Magnus Erlendsson because the ties between Scandinavia, Sweden and Norway, and Kievan Rus' were very vibrant and diverse between the tenth and thirteenth centuries; at the highest political level, dynastic marriages are especially worth mentioning. Therefore, a familiarity with Rus' literary works can be reasonably assumed (Antonsson and Garipzanov 2010, 7; Conti 2010, 194-195; Miljutenko 2006, 22-23; Ingham 1973, 7-8; Tomany 2008, 128). On the one hand, at the turn of the twelfth century, Rus' ecclesiastical figures, mostly bishops and metropolitans of Kiev originating from

12 For the critical edition of the earliest hagiographic texts on Canute, see: Gertz 1907.

13 Boris and Gleb were sons of a Kievan prince, Vladimir Sviatoslavich (980 - 1015), also known as the "baptizer" of the East Slavs due to the adoption of Christianity from the Byzantine Empire as the state religion of Rus' in 988 or 989 (Malmenvall 2015, 184-190). In 1015 Vladimir died and his son Yaroslav, at the time prince of Novgorod and later of Kiev (1019 - 1054), persuaded the Novgorodians to join him in the struggle for the Kievan throne in order to stop the rampage of Vladimir's eldest son, Sviatopolk, who in the meantime had taken the Kievan throne and had his younger brothers Boris and Gleb killed. Although Sviatopolk was the eldest living son of Vladimir Sviatoslavich and might at first glance be perceived as a rightful successor, Sviatopolk's taking of the throne was accompanied by deliberate violence - he treacherously killed off his non-resistant brothers to ensure his position. In 1019 Sviatopolk was finally defeated by Yaroslav in the Battle of the Alta River east of Kiev (Malmenvall 2015, 191-192; Senyk 1993, 225-228). Among the local Rus' saints, the cult of Boris and Gleb was the oldest and most widespread. The first phase of the canonization of the princely brothers was concluded by the confirmation of Georgi, the Kievan metropolitan, in 1072. It is 1115, however, that can be regarded as the final phase of the canonization because their relics, reposed in the town of Vyshgorod north of Kiev, were translated to a new church, dedicated to the princely brothers and built on the same site (Hollingsworth 1992, XXVIXVII; Malmenvall 2019a, 48).

14 A group of the most comprehensive as well as earliest testimonies, the so-called "Boris and Gleb cycle," consists of three texts: the report on Boris's death with the eulogy to the holy brothers included in the chronicle Tale of Bygone Years (Повпсть времяньныхь лютьв); the anonymous hagiography Tale and Passion and Encomium of the Holy Martyrs Boris and Gleb (Сказание, и страсть, и похвала, святую мученику Бориса и Гльба); and the hagiography by the monk Nestor from the Kiev Monastery of the Caves, Lesson Concerning the Life and Murder of the Blessed Passion-Bearers Boris and Gleb (Чmeнue о житии и погублении блаженую страстотерпцю Бориса и Глюба). Nestor's Lesson is certainly not the earliest of these sources, but the second or the latest. It is also stylistically and conceptually the most advanced of the entire cycle (Malmenvall 2019a, 43-44). 
the Byzantine Empire, produced a noticeable corpus of theological polemical texts written in or translated to Church Slavic, imitating the "anti-Latin" genre, which became increasingly popular in the Byzantine literature of the time, and thus criticizing the dogmatical presuppositions and liturgical practices of the Western Church. ${ }^{15}$ However, confessional differences after the schism between the Western (Catholic) and Eastern (Orthodox) Churches in 1054 did not play a major role in the context of political and economic contact between Scandinavia and Rus. ${ }^{16}$ In addition, an increasing majority of contemporary historians claim that the crucial turning point concerning the cultural and political tensions between the "Latin" and "Greek" Churches, along with their psychological alienation, occurred after the pillage of Constantinople in 1204 during the Forth Crusade (Hussey 1986, 136; Chadwick 2003, 277; Nyberg 1983).

On the territory of Rus' the veneration of royal or princely Scandinavian saints, such as Magnus Erlendsson and Canute, was clearly present. Veneration of the Scandinavian ruler saints in Rus' presents a curious instance of Christian interaction at a time when Eastern and Western Christianity, at least in general terms, were supposed to have drifted apart. However, the effects of the schism in 1054 varied from region to region, depending also on the distance from and frequency of contact with its two focal points, Rome and Constantinople. ${ }^{17}$ In this context, one can mention two interesting examples: the existence of the so-called "Varangian" or "Latin" Church for the Scandinavian merchants in twelfth-century Novgorod, dedicated to Saint Olaf (Jackson 2010, 157-161), ${ }^{18}$ and a particular Rus' liturgical source from the mid-twelfth century, found in a fifteenth-century manuscript (Lind 1990, 16-17; Jackson 2010, 166-167), conventionally called Prayer to the Holy Trinity (Rus. Молитва Святой Троице)..$^{19}$ This text is attributed to the hieromonk, renown orator and later bishop, Kiril of Turov (1130 - 1182), and contains a litany of both Eastern and Western Christian saints from various historical periods, from the first decades of Christianity to the twelfth century (Arhangel'skij 1884, 12-14). In this context, the original authorship is not important: the prayer, with its list of saints, is significant for its demonstration that a Rus' ecclesiastical writer, monk or cleric, most probably working in the mid-twelfth century, still found it acceptable to include a number of Western saints in his litany (Lind 1990, 19-20). Among Western saints, one can find names from the late antiquity, such as Martin and Victor, and early Roman pontiffs, such as Linus, Anacletus, Clement, and Leo; additionally, the prayer lists Western ruler saints from a relatively recent past, such as Wenceslaus, Magnus, and Olaf - those names are listed alongside Rus' ruler martyrs, Boris and Gleb (Lind 1990, 8-9). Magnus, placed just before the Norwegian king Olaf, the most famous of the Scandinavian ruler saints, can hardly be any other than Magnus Erlendsson (Lind 1990, 2-4, 9). Consequently, the author or compiler of the above-mentioned prayer did not only include a particular Western saint, along with many other saints from the Christian West, into an Eastern ecclesiastical context, but also connected the native martyred princes Boris and Gleb with their Western counterparts, such as Wenceslaus and

15 On this subject, see: Danilevskij 2018; Kostromin 2013b; Tachiaos 1988/1989.

16 Regarding the international relations of Kievan Rus', see: Nazarenko 2001; Kostromin $2013 a$. For a fundamental overview of the image of Byzantium and Eastern Orthodox Christianity among Scandinavia's ecclesiastical and secular elite until the early thirteenth century in terms of a (still) united Christianity with common roots, see: Jakobsson 2008.

17 For the Rus'-Scandinavian (cultural) relations in the twelfth century, see: Lind 1990; 2017.

18 For a comparative overview of Olaf's cult in the medieval Eastern Orthodox Church, see: Mel'nikova 1996. In addition, Olaf himself, according to the sagas, had spent about two years of his exile, approximately between 1027 and 1029, in Rus' at the court of Yaroslav Vladimirovich (Skórzewska 2011, 339, 344; Jackson 2010, 153-154; Jónsson 1914, 201).

19 This text was published in its entirety by the Russian literary historian Alexander Semyonovich Arkhangelskiy (1854 - 1926) (1884). 
Magnus. By doing this he indirectly acknowledged ruler martyrs on the periphery of Europe of the time as a special (sub)category of common Christian saints.

Despite the above-mentioned vibrant and non-conflictual relations between Rus' and Scandinavia until the early thirteenth century, which could have exerted their influence also on the mutual acquaintance with their ruler martyrs and borrowings of literary motifs concerning their hagiographic reports, the most reliable explanation of the similarities between Boris and Gleb and Magnus is to recognize a hagiographic pattern: this pattern closely corresponds to Christ's passion, that was adopted almost simultaneously and mostly independently by hagiographers and other writers working in the peripheral newly Christianized parts of Europe. Their purpose was to give meaning to the political killings of princely figures in terms of martyrdom and, consequently, religious "maturity" of these lands. Hence, various writers of such hagiographic and historical texts came to similar conclusions in pursuing similar (spiritual) goals stemming from similar political and cultural circumstances.

\section{Conclusion}

The existence of ruler martyrs among the ruling secular elite was, despite local differences and specific reasons for specific canonizations, common in the polities on the eastern and northern periphery of Europe that had recently adopted Christianity. A representative case within the phenomenon of ruler martyrs can also be recognized in Magnus Erlendsson, jarl (earl) of the Orkney Isles, who was murdered by his cousin, Haakon Palsson. The internal political plot led by a close relative, the jarl's nonresistance on principle, the last-hour praying and attendance at mass, the final encirclement and slaughter of the victim as the "innocent lamb" resembling Christ - all this recalls vividly the manner of the deaths of some Slavic princes of the time, such as Boris and Gleb of Kievan Rus'. Furthermore, Magnus's martyrdom seems to be subversive in relation to the generally accepted warrior values in the Scandinavian sagas. The saint's life and death represent an example where the ideal of fame is dealt in a Christian fashion, giving precedence to self-sacrifice for others and eternal "heavenly glory" over instant military and political success. Like Christ, who gave his own life for the peace and redemption of the world, Magnus gives his life for the peace and redemption of the people of the Orkneys - thus symbolically integrating them into "salvation history" shared by all other Christian polities.

Regarding the typology of the cults of martyr rulers on the eastern and northern periphery of medieval Europe, particularly in case of Magnus Erlendsson and Boris and Gleb, and any possible external influence on them, the absence of direct parallels in the previous Byzantine and Latin hagiographical necessitates considering a broader European context of princely or royal sainthood. Potential sources of mutual influence on the eastern and northern periphery of medieval Europe are connected with merchant ties, cultural communication, and with the intense diplomatic contact and far-reaching dynastic links - rather than reliable textual evidence. So far none of the relevant studies can be considered a final solution to the question of whether one can interpret existing similarities as transregional parallelisms or direct borrowings (Paramonova 2010, 272273, 282). First of all, since the mentioned Scandinavian saints, such as Magnus or Canute, are later than their Slavic counterparts, such as Wenceslaus or Boris and Gleb, it is obvious that they cannot have been known to the writers of the first Slavic texts. Any possible influence in the early period could only have been from East to West. In this political framework, internal dynastic and kinship connections - the interdependence between the (regional) princes from the same dynasty themselves and a specific prince and his druzhina - remained the crucial model for settling internal disputes. The veneration of Boris and Gleb thus served as a kind of "sacralization" of the ruling 
dynasty in the sense of showing the practical realization of the Christian identity of the Rurik dynasty. In hagiographic representation, the internal dynastic and kin relations of the saints were reshaped according to Christian norms and virtues, such as peacefulness, humility, and (brotherly) love. Moreover, these relations acquired their own religious meaning and formed a broader historical and theological framework, that of salvation history, within which such Christian virtues could be realized and emphasized (Paramonova 2010, 282; Ingham 1973, 11).

The problem with a comparative analysis of hagiographic texts, however, is that it is hard to distinguish between details and motifs that would allow creating broader models and patterns and those details and motifs that can result from coincidence. Similarities between different narratives can easily be explained by a universal model of imitation of Christ. Therefore, many details that can be found in the hagiographic stories can be seen as results of an attempt to portray the martyr as an image of Christ. Details that tend to reenact Christ's life and death, taken together, construct unique narrative patterns - in this respect, Magnus of Orkney is the best example of a narrative parallel with the Boris and Gleb cycle. The result of unique patterns that share similarities is a phenomenon of a martyred ruler that developed between the tenth and twelfth centuries. Martyred rulers from that period together formed a new tradition of ruler's martyrdom where the ruler could become a martyr because he was a good, righteous ruler who died an innocent death, showing no resistance, only his willingness to be a martyr for a greater good, to be an imitator of Christ. Thus, he became also a local saint who could legitimize the existence of newly Christianized peoples and position them at the same time in the symbolic center of the Christian world by forging a covenant between them and the Lord (Trajković-Filipović 2013, 1516; Klaniczay 2002, 99, 398).

\section{REFERENCES}

Antonin, Robert. 2017. The Ideal Ruler in Bohemia. Leiden.

Antonsson, Haki. 2004. Two Twelfth-Century Martyrs: St Thomas of Canterbury and St Magnús of Orkney. In Williams, Gareth - Bibire, Paul (eds.). Sagas, Saints and Settlements. Leiden, 41-64. Antonsson, Haki. 2006. St. Magnús of Orkney: Aspects of his Cult from a European Perspective. In Owen, Olwyn (ed.). The World of the Orkneyinga Saga: The Broad-cloth Viking Trip. Kirkwall, 144-159.

Antonsson, Haki. 2007. St. Magnús of Orkney. A Scandinavian Martyr-Cult in Context. Leiden.

Antonsson, Haki - Garipzanov, Ildar H. 2010. Introduction: The Veneration of Saints in Early

Christian Scandinavia and Eastern Europe. In Antonsson, Haki - Garipzanov, Ildar H. (eds.).

Saints and their Lives on the Periphery: Veneration of Saints in Scandinavia and Eastern Europe (c. 1000 - 1200). Turnhout, 1-14.

Arhangel'skij, Aleksandr S. 1884. Любопытный памятник русской письменности XV века [Interesting Monument of Russian Litteracy of the 15th Century]. In Памятники древней письменности [Monuments of the Ancient Litteracy] 50, 1-19.

Bagge, Sverre. 2011. The Europeanization of Europe: The Case of Scandinavia. In Noble, Thomas F. X. - Engen, John V. (eds.). European Transformations: The Long Twelfth Century. Notre Dame, 171-193.

Beuermann, Ian B. 2011. Jarla Sogur Orkneyja. Status and Power of the Earls of Orkney According to their Sagas. In Steinsland, Gro et al. (eds.). Ideology and Power in the Viking and Middle Ages: Scandinavia, Iceland, Ireland, Orkney and the Faeroes. Leiden, 109-161.

Blindheim, Martin. 1988. St. Magnus in Scandinavian Art. In Crawford, Barbara (ed.). St. Magnus Cathedral and Orkney’s Twelfth-Century Renaissance. Aberdeen, 165-183. 
Chadwick, Henry. 2003. East and West: The Making of a Rift in the Church. From Apostolic Times until the Council of Florence. Oxford.

Conti, Aidan. 2010. Ælnoth of Canterbury and Early Mythopoiesis in Denmark. In Antonsson, Haki - Garipzanov, Ildar H. (eds.). Saints and their Lives on the Periphery: Veneration of Saints in Scandinavia and Eastern Europe (c. 1000 - 1200). Turnhout, 189-206.

Cubitt, Catherine. 2000. Sites and Sanctity: Revisiting the Cult of Murdered Anglo-Saxon Royal Saints. In Early Medieval Europe 9/1, 53-83.

Danilevskij, Igor' N. 2018. Антилатинская полемика на Руси в XI - XII веках [Anti-Latin Polemics in Rus' in 11th-12th Centuries]. In Nagirnyy, Vitaliy (ed.). Colloquia Russica 8: Religions and Beliefs of Rus' (9th-16th Centuries). Cracow, 115-129.

Dubois, Thomas A. 2008. Introduction. In Dubois, Thomas A. (ed.). Sanctity in the North: Saints, Lives, and Cults in Medieval Scandinavia. Toronto, 3-28.

Gertz, Martin C. 1907. Knud den Helliges martyrhistorie saerlig efter de tre aeldste kilder. Copenhagen.

Girard, René. 1987. Things Hidden Since the Foundation of the World: Research Undertaken in Collaboration with Jean-Michel Oughourlian and Guy Lefort. Stanford.

Guðmundsson, Finbogi (ed.). 1965. Orkneyinga saga. Legenda de Sancto Magno. Magnúss saga skemmri. Magnúss saga lengri. Helga páttr ok Úlfs. Reykjavik.

Hafner, Stanislaus. 1964. Studien zur altserbischen dynastischen Historiographie. Munich.

Heinzelmann, Martin. 1979. Translationsberichte und anderen Quellen des Reliquienkultes. Turnhout.

Hoffmann, Erich. 1975. Die heiligen Könige bei den Angelsachsen und den skandinavischen Völkern. Königsheiliger und Königshaus. Neumünster.

Hollingsworth, Paul. 1992. The Hagiography of Kievan Rus'. Cambridge, MA.

Hussey, John M. 1986. The Orthodox Church in the Byzantine Empire. Oxford.

Ingham, Norman W. 1973. The Sovereign as Martyr, East and West. In The Slavic and East European Journal 17/1, 1-17.

Ingham, Norman W. 1984. The Martyred Prince and the Question of Slavic Cultural Continuity in the Early Middle Ages. In Birnbaum, Henrik - Michael S. Flier (eds.). Medieval Russian Culture 12. Berkeley, 31-53.

Ingam, Norman. 1990. Мучеништво светог Јована Владимира Дукљанина [Martyrdom of Saint Jovan Vladimir of Dioclea]. In Летопис Матице Српске [Annals of the Matica Srpska] 166, 876-896.

Jackson, Tatjana N. 2010. The Cult of St Olaf and Early Novgorod. In Antonsson, Haki - Garipzanov, Ildar H. (eds.). Saints and their Lives on the Periphery: Veneration of Saints in Scandinavia and Eastern Europe (c. 1000 - 1200). Turnhout, 147-167.

Jakobsson, Sverrir. 2008. The Schism that Never Was: Old Norse Views on Byzantium and Russia.

In Byzantinoslavica - Revue internationale des Études Byzantines 1/1-2, 173-188.

Jesch, Judith - Molleson, Theya. 2006. The Death of Magnus Erlendsson and the Relics of

St. Magnus. In Owen, Olwyn (ed.). The World of the Orkneyinga Saga: The Broad-cloth Viking Trip. Kirkwall, 127-143.

Jónsson, Finnur (ed.). 1914. Den Norsk-Islandske Skjaldedigtning, A, vol. 1. Copenhagen.

Kantor, Marvin (ed.). 1983. Medieval Slavic Lives of Saints and Princes. Ann Arbor.

Klaniczay, Gábor. 2002. Holy Rulers and Blessed Princesses: Dynastic Cults in Medieval Central Europe. Cambridge.

Kostromin, Konstantin A. 2013a. Церковные связи Древней Руси с Западной Европой (до середины XII в.). Страницы истории межконфессиональных отношений 
[Ecclesiastical Ties of Rus' with the Western Europe (Until the Mid-13th Century). Pages of History of Interconfessional Relations]. Saarbrücken.

Kostromin, Konstantin A. 2013b. Развитие антилатинской полемики в Киевской Руси (XI середина XII в.). Страницы истории межцерковных отношений [Development of AntiLatin Polemics in Kievan Rus' (11th - mid-12th Century). Pages of History of Interconfessional Relations]. Saarbrücken.

Kostromin, Konstantin A. 2018. Владари-мученици у словенским земљама у периоду покрштавања Источне Европе [Ruler Martyrs in Slavic Lands during the Period of Christianization of Eastern Europe]. In У спомен и славу Светог Јована Владимира 6/1: Међународни научни скуп Свети Јован Владимир кроз вјекове - историја и предање (1016 - 2016), Бар, 15 - 17. септембар 2016. године [To the Memory and Glory of Saint Jovan Vladimir 6/1: International Scientific Conference Saint Jovan Vladimir through Centuries History and Tradition (1016 - 2016), Bar, 15th - 17th September 2016]. Cetinje, 81-104.

Lamprou, Soultana - Zozul'aková, Viera. 2019. The abolition of Ethnic, Racial, or Cultural Distinctions in the Apostle Paul. Indicative Patristic Approach. In Konštantínove listy [Constantine's Letters] 12/2, 33-42.

Lind, John H. 1990. The Martyria of Odense and a Twelfth Century Russian Prayer. To the Question of Bohemian Influence on Russian Religious Literature. In Slavonic and East European Review $68,1-21$.

Lind, John H. 2017. Varangian Christianity and the Veneration of Anglo-Saxon and Scandinavian Saints in Early Rus'. In Callmer, Johan - Gustin, Ingrid - Roslund, Mats (eds.). Identity Formation and Diversity in the Early Medieval Baltic and Beyond. Leiden, 107-135.

Lundegårdh, Ingrid. 1997. Kampen om den norrländska Olavskulten. In Rumar, Lars (ed.). Helgonet i Nidaros: olavskult och kristnande i Norden. Stockholm, 128-136.

Malmenvall, Simon. 2015. Kijevska Rusija in Pripoved o minulih letih. In Podlesnik, Blaž (ed.). Pripoved o minulih letih. Ljubljana, 175-239.

Malmenvall, Simon. 2017a. Narativni teksti o Borisu in Glebu med posredovanjem političnega zgleda in tolmačenjem zgodovine. In Slavistična revija 65/2, 312-322.

Malmenvall, Simon. 2017b. Zgodovina odrešenja v ekumenski perspektivi. In Bogoslovni vestnik 77/1, 67-78.

Malmenvall, Simon. 2018. Salvation History in Fides et Ratio: Theological (Ecumenical) and Historiographical Implications. In Bogoslovni vestnik 78/2, 387-400.

Malmenvall, Simon. 2019a. Boris and Gleb: Political and Theological Implications of Overcoming Violence through Sacrifice in Kievan Rus'. In Konštantínove listy [Constantine's Letters] 12/2, 43-58.

Malmenvall, Simon. 2019b. Kultura Kijevske Rusije in krščanska zgodovinska zavest. Ljubljana.

Malmenvall, Simon. 2019c. Ruler Martyrs among Medieval Slavs: Boris and Gleb of Rus' and Jovan Vladimir of Dioclea. In Orientalia Christiana Periodica 85/2, 395-426.

Mel'nikova, Elena A. 1996. Культ Св. Олава в Новгороде и Константинополе [Cult of Saint Olaf in Novgorod and Constantinople]. In Византийский временник [Byzantine Journal] $56,92-106$.

Miljutenko, Nadežda I. 2006. Святые князья-мученики Борис и Глеб: Исследование и тексты [Holy Princely Martyrs Boris and Gleb: Research and Texts]. Saint-Petersburg.

Mooney, John. 1935. St. Magnus - Earl of Orkney. Kirkwall.

Mortensen, Lars B. 2006. Sanctified Beginnings and Mythopoietic Moments. The First Wave of Writing on the Past in Norway, Denmark and Hungary, c. 1000 - 1230. In Mortensen, Lars B. (ed.). The Making of Christian Myths in the Periphery of Latin Christendom (c. 1000 - 1300). Copenhagen, 247-274. 
Mortensen, Lars B. - Mundal, Else. 2003. Erkebispesetet i Nidaros - arnestad og verkstad for Olavslitteraturen. In Imsen, Steinar (ed.). Ecclesia Nidrosiensis 1153-1537. Søkelys på Nidaroskirkens og Nidarosprovinsens Historie. Trondheim, 353-384.

Nazarenko, Aleksandr V. 2001. Древняя Русь на международных путях: междисциплинарные очерки культурных, торговых, политических связей IX - XII веков [Rus' on the International Paths: Interdisciplinary Sketches of Cultural, Trade, and Political Relations between the 9th and 12th Centuries]. Moscow.

Nyberg, Tore. 1983. Deutsche, dänische und schwedische Christianisierungsversuche östlich der Ostsee im Geiste des 2. und 3. Kreuzzuges. In Nowak, Zenon H. (ed.). Die Rolle der Ritterorden in der Christianisierung und Kolonisierung des Ostseegebietes. Toruń, 93-114.

Paramonova, Marina. 2010. The Formation of the Cult of Boris and Gleb and the Problem of External Influences. In Antonsson, Haki - Garipzanov, Ildar H. (eds.). Saints and their Lives on the Periphery: Veneration of Saints in Scandinavia and Eastern Europe (c. $1000-1200)$. Turnhout, 259-282.

Petkovšek, Robert. 2018. Svoboda med žrtvovanjem in darovanjem. In Bogoslovni vestnik 78/1, 33-51.

Price, Richard M. 1993. Boris and Gleb: Princely Martyrs and Martyrology in Kievan Russia. In Wood, Diana (ed.). Martyrs and Martyrologies. Oxford, 105-115.

Sciacca, Francis A. 1990. In Imitation of Christ: Boris and Gleb and the Ritual Consecration of the Russian Land. In Slavic Review 49/2, 252-260.

Senyk, Sofia. 1993. A History of the Church in Ukraine, vol. 1: To the End of the Thirteenth Century. Rome.

Skórzewska, Joanna A. 2011. Family Matters? The Cultus of the Scandinavian Royal Martyrs. In Steinsland, Gro et al. (eds.). Ideology and Power in the Viking and Middle Ages: Scandinavia, Iceland, Ireland, Orkney and the Faeroes. Leiden, 329-365.

Tachiaos, Anthony-Emil N. 1988/1989. The Greek Metropolitans of Kievan Rus': An Evaluation of Their Spiritual and Cultural Activity. In Harvard Ukrainian Studies 12-13, 430-445.

Thomson, William P. L. 1987. History of Orkney. Edinburgh.

Tomany, Maria-Claudia. 2008. Sacred Non-Violence, Cowardice Profaned: St Magnus of Orkney in Nordic Hagiography and Historiography. In Dubois, Thomas (ed.). Sanctity in the North: Saints, Lives, and Cults in Medieval Scandinavia. Toronto, 128-153.

Trajković-Filipović, Stefan. 2012. Saint Vladimir of Zeta Between Historiography and Hagiography (MA Thesis in Medieval Studies). Budapest.

Trajković-Filipović, Stefan. 2013. Inventing a Saint's Life: Chapter XXXVI of The Annals of a Priest of Dioclea. In Revue des études Byzantines 71/1, 259-276.

Vandvik, Eirik (ed.). 1959. Latinske dokument til Norsk historie, vol. 2. Oslo.

Vigfusson, Gudbrand (ed.). 1893. Icelandic Sagas and Other Historical Documents Relating to the Settlements and Descents of the Northmen on the British Isles, vol. 3: The Orkneyingers' Saga, with Appendices. London.

Vigfússon, Gudbrand - Unger, Carl R. (eds.). 1860 - 1868. Flateyjarbók: En samling af norske konge-sagaer med indskudte mindre fortællinger om begivenheder i og udenfor Norge samt annaler, 3 vols. Oslo.

Waugh, Robin. 2003. Saint Magnus's Fame in Orkneyinga Saga. In The Journal of English and Germanic Philology 102/2, 163-187.

White, Monica. 2010. Byzantine Saints in Rus' and the Cult of Boris and Gleb. In Antonsson, Haki - Garipzanov, Ildar H. (eds.). Saints and their Lives on the Periphery: Veneration of Saints in Scandinavia and Eastern Europe (c. 1000 - 1200). Turnhout, 95-114. 
doc. dr. Simon Malmenvall

Catholic Institute

Faculty of Law and Business Studies

Chair of Philosophy, Religious Studies, and Applied Ethics

Krekov trg 1

1000 Ljubljana

Slovenia

simon.malmenvall@kat-inst.si

University of Ljubljana

Faculty of Theology

Chair of Fundamental Theology and Dialogue

Poljanska 4

1000 Ljubljana

Slovenia

simon.malmenvall@teof.uni-lj.si 